udc 791:[371.3:7

doi 10.18485/bells.2015.7.8

\author{
Cecilia Beecher Martins \\ University of Lisbon \\ ULICES - University of Lisbon Centre for English Studies
}

\title{
FREE ASSOCIATIVE FILM ANALYSIS ${ }^{1}$
}

\begin{abstract}
Can people's lives be enhanced through personal reflective contact with the arts? Results obtained from social intervention programs using the arts, including music (Tunstall 2012) and literature (Trounstine \& Waxler 2008) indicate this is the case. In Meeting Movies (2006) Norman Holland demonstrates a reflective method of film analysis - free associative film analysis. In this essay, I will present my adaptation of this method, the results I obtained from individual free associative film analysis and its application in the classroom. I will examine the outcomes obtained in light of proposals made by philosopher Miranda Fricker on epistemic injustice (2007), and Byung-Chul Han on the social and neural roots of neurological illness such as depression, attention deficit hyperactivity disorder (ADHD), borderline personality disorder (BDO) and burnout syndrome today (2010). Based on these reflections, I will suggest that perhaps there has never been a greater need to study the arts.
\end{abstract}

Key words: cinema, the arts, education, free associative film analysis, social intervention.

\footnotetext{
1 The essay "Free Associative Film Analysis" is an output of research developed under the Doctoral Grant (SFRH/BD/44049/2008) supported by Portuguese Foundation for Science and Technology (FCT), ULICES and the Project Medicine \& Narrative - (Con)texts and practices across disciplines (PTDC/CPC-ELT/3719/2012). I would also like to thank Marijke Boucherie, Fernando Martins and Kevin Phelan for their diligent questioning of my work in general, which has strengthened it, and their proof reading of this article in particular.
} 


\section{Introduction}

In today's technologically driven digital world the advantages of studying the arts, film and literature in particular, is often questioned. However, in this essay I will argue that despite some contrary opinions there has never been a more appropriate time to do just that. I will propose that reflective analysis of the arts offers a unique space to gain awareness and acceptance of self, permitting the consideration of new and challenging ideas which may enhance people's ideas about what the world might be or become for them. Indeed, when encountered reflectively the arts may act as transitional and transformational objects just as psychoanalytical literary critic Norman Holland proposed in his essay "The Mind and the Book" (1998). Holland's suggestion is vindicated today by the variety of arts and literature programs achieving exemplary results in challenging environments. I will begin this essay with a very brief overview of some programmes that demonstrate the power of reflective contact with the arts. I will then present the results obtained from a contemplative form of film criticism - free associative film analysis - both in individual film analysis and in a classroom application ${ }^{2}$. I will end the essay discussing the results of all the programmes presented in light of proposals made by philosophers Miranda Fricker (2007) and Byung-Chul Han (2010) on respectively, epistemic injustice and the social and even neural roots of disorders prevalent in today's society.

\section{Arts and literature programmes that are changing lives}

Because of the range of scope of programmes available, this will have to be a brief overview indeed. However, the programmes selected demonstrate the power of reflective contact with the arts. I chose these particular programmes because while they are supported by formal educational structures ${ }^{3}$, they look to developing individual contact

2 The free associative film analysis method used was based on the work of Holland (2006) and Holland \& Schwartz (2008).

3 El Sistema is normally run through state primary and middle schools. Most of the CLTL programmes in the USA are supported by University Departments, as are the Writing Workshops run in Unidad Penitenciaria 48, Buenos Aires, Argentina. 
between participants and the art form studied rather than trying to teach a particular interpretation or application. Their central premise is that it is this encounter that changes lives. Despite the fact that they do not set out to teach formal interpretations they require diligence as the uninstructed learn to dominate new and complex techniques whether this be playing a musical instrument in harmony with others or reading a novel in such a way that a personal opinion can be formed and articulated. They focus on creativity as young minds are encouraged to write their own songs and musical pieces; or adults in jail write their first poems about life and hope (Domenech 2014).

I will begin with José Abreu's El Sistema, a musical education programme begun in Venezuela in the 1970s because it is probably one of the most documented and internationally adapted social intervention programmes based on the arts in operation today. Abreu's goal was to show children living in impoverished neighbourhoods - many with serious drug and gang related crime problems - that there could be alternatives to the way of life surrounding them. He felt this could be achieved by instilling a love for music in these children, and teaching them how to work together in a harmonious fashion. He began by teaching singing, followed closely by composition and then teaching children to play musical instruments by imitating their teachers. It worked, and the first youth orchestras were born. El Sistema has been so successful in breaking cycles of poverty, drug abuse and drug related crime that it has been adopted throughout Latin America, the US, Canada and the UK (Tunstall 2012). Most European countries run El Sistema programmes today. Examples are the Generation Orchestra in Portugal and the Sing Out with Strings project in Ireland. The Generation Orchestra began in 2005 in Amadora, a socially challenged city on the fringes of Lisbon. It has spread to other cities over the last ten years ${ }^{4}$. The Sing Out with Strings ${ }^{5}$ project supported by the Irish Chamber Orchestra as a Community Engagement Programme operating under the umbrella of Limerick's Regeneration Process is now a feature of primary school education in problematic areas in the city's inner city. Both are seen as offering alternatives to young people growing up in socially challenging areas. Start-ups of El Sistema have begun in Angola and Mozambique (ibid).

4 More information can be found at http://www.orquestra.geracao.aml.pt/en/the-project

5 For more details consult http://www.irishchamberorchestra.com/community-engagement/ sing-out-with-strings 
In the field of literature, the Changing Lives Through Literature (hereafter CLTL) programme, operating in prison systems, also follows the principle that reflective contact with the arts can change lives. The progamme arose out of English Professor, Robert Waxler's belief in the transformative and humanizing power of literature. Waxler developed CLTL while working in the English Department at the University of Massachusetts. He was able to count with the support of District Court Judge Robert Kane who had become increasingly frustrated at the high levels of recidivism and lack of rehabilitation he encountered in the American Justice System. Waxler convinced Kane to consider offering a literature programme as an alternative or commuting option to a prison sentence. In Finding a Voice (2005), Jean Trounstine and Waxler demonstrate how a reflective approach to teaching literature can return the formerly disenfranchised to society, giving them an individual voice and broader social awareness. The first CLTL program took place in the fall of 1991 and three subsequent courses ran over the following year (2008: 62-81). Recidivism among graduates of these first four CLTL programs was much lower than among felons who did their complete prison sentences (19\% as compared with $45 \%$ respectively). If offenders returned to crime there was a reduction in the level of violence (ibid: 4). Low self-esteem, limited and limiting life experiences are common traits in participants on CLTL (ibid: 5355). Graduates' testimonials illustrate how reading books and discussing interpretations helped them gain new perspectives, develop empathy, hope, a wider understanding of society, and gain self-esteem (ibid: 2-3, 5, 10, 24-26). This contact with literature often gave participants their first positive role models as illustrated by Antonio's story. Antonio testified that Hemingway's Santiago in The Old Man and the Sea, inspired him to refrain from relapsing into his prior drug-abuse lifestyle (ibid: 29-30).

Trounstine comments that a vital aspect of the CLTL courses for women she worked with was finding positive female role models in literature whether they were the characters in their books or the authors themselves. In contrast to men, most of whom had families who supported them and desired change, some women had abusive partners who did not want them to find an individual voice. Others were raising children on their own. If they were doing CLTL as a parole option, they were juggling very hectic lives trying to secure jobs and raise families. They often felt inadequate, defeated and alone in the middle of these struggles, thus literature was one of the only places they could see women who had survived and raised 
about circumstances like their own. Books like Toni Morrison's The Bluest Eye, and stories like Tillie Olsen's "I Stand Here Ironing" allowed them to talk about the problems that were part of their day-to-day lives without feelings of guilt or shame. They gained new and different perspectives as they discussed their reactions to/impressions of fictional characters who represented realities of their lives. Discussing texts, encountering kindred responses allowed them to feel that they belonged to a larger community. They were not alone in their struggles. They didn't like all the books and struggled with some like Silvia Plath's The Bell Jar, but they were able to read and have independent opinions about them, which was a huge achievement (2008: 83-95).

Since 1991, the programme has gone from strength to strength and has been adapted and used in more than twenty states in the US and other countries including Canada and the UK, where the Writers in Prison Network support the "Stories Connect" project based on CLTL (2008: 101-30). Another interesting literature based programme is the Writing Workshops run by the Universidad Nacional de San Martin, in the Unidad Penitenciaria 48, Provincia de Buenos Aires, Argentina (Domenech 2014).

\section{Free Associative Film Analysis - Introducing the Method}

In Meeting Movies (2006), Norman Holland wrote "to meet a movie is to meet oneself, and that is what I am inviting you to do" (2006: 14). As part of my doctoral research I decided to accept Holland's challenge and investigate first, if free associative film analysis could function as a tool of self-awareness as Holland suggested, second, to try to understand its benefits and consequences. The method developed was adapted from that presented by Holland in Meeting Movies, as well as Holland and Schwartz in Know Thyself (2008). The former contains Holland's personal free associations to eight films, the latter, detailed instruction on teaching free associative literary analysis. In Know Thyself Holland and Schwartz introduced students to psychoanalytical principles, including Lichtenstein's unique identity theme theory and Waelder's principle of multiple function related to the balance of internal and external demands that are related to ego, id and superego (2008: 3-5), I did not want to place such an emphasis on psychoanalytical theory. Rather I wished to explore that unique space between viewer and movie. Thus I did not include much psychoanalytical 
theory, just instruction on free associative film analysis and a simplification of Heinz Lichtenstein's unique identity theme theory.

Based on his clinical practise, Lichtenstein proposed that every individual had a unique way of interacting with the world, but that no identity theme can or should be seen as superior to another. Rather, what is relevant is to understand one's own identity theme and to make important decisions in light of this (Lichtenstein: 1977). Holland started to use this principle because he had seen unique patterns in readers' free associative literary analysis as he presented in 5 Readers Reading (Holland: 1975). He felt people could gain insight into their unique identity theme through understanding relevant connections. This could help them understand, their unique way of interacting with the world and why they felt comfortable in some attitudes and less content with others. This is what he meant when he wrote, "to meet a movie is to meet yourself, and that is what I am inviting you to do" (2006: 14). I wondered if this comprehension could be used to help people understand the positions they assumed and gain awareness and acceptance of self, as according to Lichtenstein there is no good or bad identity theme.

\section{Free Associative Film Analysis - working with individuals ${ }^{6}$}

The methods used followed the patterns below which were adjusted for individual cases. First, participants watched the movie to be analysed with a supervisor in order to assist the viewer select individual connection points for subsequent free associative analysis. Second, they were instructed in the free associative film analysis methods, so they learned to write first analytically and then to follow thought patterns arising from these analytical strands. They wrote the former in regular print, the latter in italics. Third, they wrote free associative analysis to those specific points over a one to three-week period. The texts produced were discussed with a

\footnotetext{
${ }^{6}$ Because of the scope of this essay, I cannot include complete instruction on the free associative film analysis method, but this can be found in the doctoral thesis Simple Stories (2012) and the chapter "Gaining Awareness and Acceptance of Self and Developing Coping Skills through Film Analysis" in Narritiva e Bioetica (2015: 117-132). These cases were also presented as a poster presentation "Free Associative Film Analysis - offering new perspectives" at the $16^{\text {th }}$ International Neuropsychoanalysis Conference in Amsterdam from 9-12th July 2015.
} 
supervisor, who helped them see patterns in interpretations, demonstrative of the participants' unique and individual way of seeing the world and interacting with their surroundings. Follow-up work was developed as appropriate for each case.

I will present a very brief overview of the outcomes obtained by three participants in this project, Aida, Anna and Anita (all fictional names) because these exemplify the types of results obtained. Because of the reductions in anxiety levels registered in other film analysis trials (Martins 2012), Anna and Anita's free associative film analysis was also accompanied by Charles Spielberger's State and Trait Anxiety Inventory (hereafter STAI) to offer quantitative results.

\section{Outcome of Aida's free associative film analysis:}

Aida (Martins 2012: 152-162) the first volunteer was a successful 23-year old graduate at the beginning of an interesting career. She participated in the project because she wanted to learn more about herself and wanted to see if her free associative film analysis would vindicate unusual lifestyle choices that had worked well for her. She began free associative film analysis in March 2009 and did the final feedback interview in May 2011. She analysed Mini Leder's Pay It Forward (2000), her free associative choice. As can be seen from an excerpt taken from her texts, free associative film analysis helped her to be more comfortable about her "natural" tendencies, and aided her in embracing her lifestyle, which actually suited her very well:

It [performing free associative film analysis] was very beneficial as it made me aware of some of the things that are important to me. It made me more conscious of who I am/ want to be. It is not only an analysis of the past but the creation of awareness towards the future. I also believe that by doing it constantly (through films, books and perhaps some situations) we can gradually learn about and build our identity (ibid: 161). 


\section{Outcomes of Anna's free associative film analysis:}

Anna (ibid: 166-187) was 25 years old and also a successful graduate at the beginning of an interesting career when she participated in the trials. She was the first member of a Portuguese working class family to obtain a university degree, but despite her success, she had very serious feelings of personal inadequacy. She took part in the project because she hoped it might shed light on how a "hard-nosed" unromantic professional could take such pleasure in light-hearted romantic comedies like Dirty Dancing (the film she chose to analyse free associatively) and maybe also to learn a little more about herself. She began free associative film analysis in October 2009 and did the final feedback interview in June 2011.

She had chosen this film because she associated with the character of Baby. In this film, despite the nickname, Baby, is a strong character: hardworking, intelligent, mature and insightful. However, Anna had inverted the power positions in her interpretation of the character in her analysis, and cast Baby as vulnerable and in danger of abandonment. In the discussion of her texts, we correcting this interpretation and this helped Anna reconsider her own sense of self-worth. The discussion of her texts also allowed Anna to understand her connection romantic comedies like Dirty Dancing in a non-judgemental way and enabled her to change previously destructive lifestyle habits. It let her consider that she could aspire to happiness also. Anna wrote:

It [performing free associative analysis to Dirty Dancing] allowed me to get to know myself better and begin a process of self-motivation and appreciation. I began to understand many things about myself, especially how I had been influenced by my upbringing and the environment I live in. I admit, on the one hand, that I have not been able to put everything I have learned into practice, on the other, I know that this is a task for the rest of my life. Since I began the project, I have changed a lot and I believe that I am moving a little in the right direction every day (ibid: 176).

Anna was the first participant doing free associative film analysis to also complete the STAI questionnaires. The outcomes obtained from these questionnaires support the sentiments she expressed in her free associative film analysis texts. STAI measurements are classified in the following manner: 20-39 Low, 40-59 Medium, 60-80 High. Anna's SA (State Anxiety) 
levels dropped ten points from 46/80 to 35/80 over the course of the work. More significantly her TA (Trait Anxiety) dropped from 61/80 (High) to $34 / 80$ (Low) over the same period. These outcomes were very significant because according to Spielberger, TA should remain quite constant throughout life (1983: 1-5). Such a reduction implies a very significant change in general outlook on life. Also the fact that Anna's final SA and TA readings were similar, implies balance between state of mind at the time and a general mode of thinking. Could one be so bold as to suggest that Anna not only acquired awareness, but also acceptance of self through free associative film analysis.

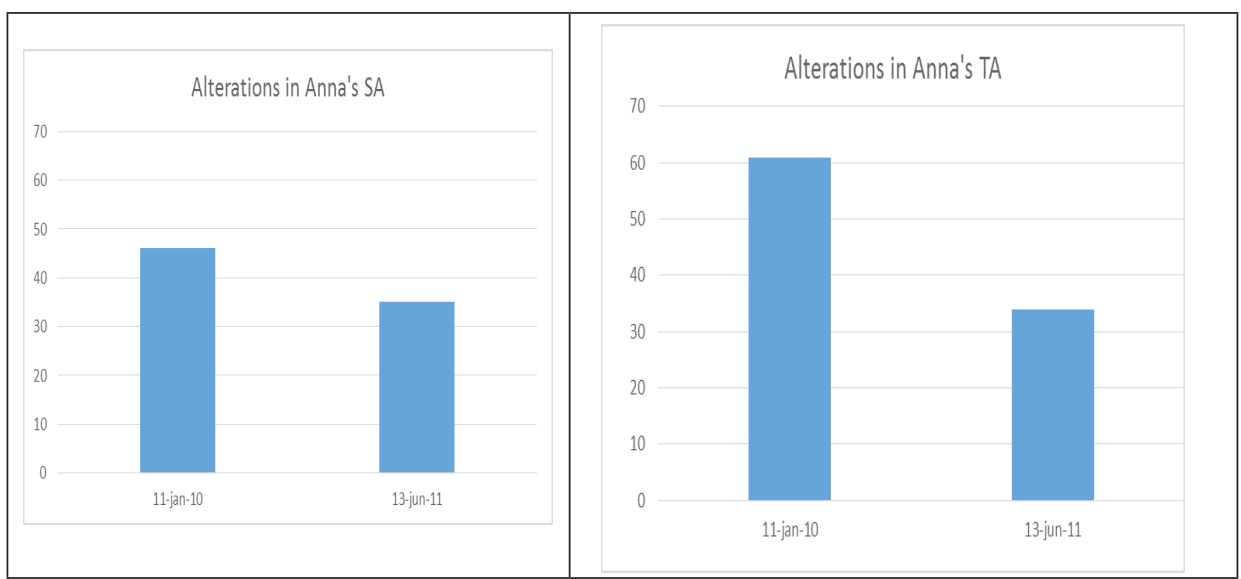

Fig 1 Anna's STAI Results

\section{Outcome of Anita's free associative film analysis:}

Anita (ibid: 328-356) was a 17-year old high-school student when she participated in the trials. Despite being intelligent, she was despondent and without motivation. She was suffering from high anxiety at the time we worked together. She did free associative film analysis to Cameron Crowe's Elizabethtown (2005). I chose this film because of the very significant reductions in anxiety levels registered when groups watched this movie. We worked together actively from December 2010 to January 2011 and she worked on her own from January to June 2011. She wrote that performing 
free associative film analysis helped her gain perspective on her situation and regain goals, "It helped me to understand and accept my biology better and to accept "my failings", my anxiety. It also helped me to understand the importance of being unique. This encountering of our personality allows us to find happiness" (ibid: 355). It also allowed her to develop techniques to deal with anxiety cycles, and subsequently significant reductions in both state and trait anxiety levels were registered. TA drops from 69/80 to $52 / 80$ in the seven-month period. Her SA remains within the $30-40 / 80$ range over the period, achieving an all-time low at 26/80 after she watched Elizabethtown on $26^{\text {th }}$ Nov 2010.

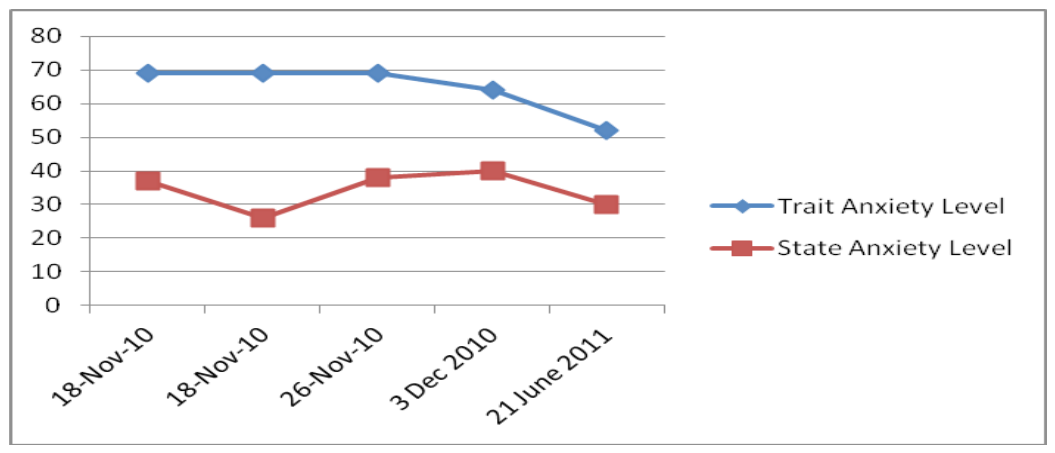

Fig 2 Anita's STAI results

\section{Overview of the results of individual free associative film analysis}

The outcomes obtained far exceeded expectations. Performing free associative film analysis led not only to awareness, but also acceptance of self as well as the capacity to develop new habit and thinking patterns when necessary. While individual approaches were applied in each case, three common procedural elements became evident. First, once connection points had been selected, free associative film analysis writing should be conducted by the individual in isolation. Second, discussing the written free associative analysis texts was necessary for participants to understand their significance to them. Third, thoughts and ideas obtained from the free associative analysis texts could be used to break destructive habit and 
thinking patterns, and to construct new ones. Viewing the outcomes, I considered that perhaps the greatest advantage of free associative film criticism was that it permitted a time of constructive reflection, in a nonjudgmental environment, and that this also allowed for change.

\section{Free Associative Film Analysis in the Classroom}

On finishing my doctoral research, I was encouraged by colleagues to follow the psychological/psychoanalytical aspects of this work, and initially I was tempted to do this. However, I quickly learned that this was not actually what interested me, or even that which distinguished the work. Reviewing the whole body of research, it was very clear that the central and defining point had always been film analysis, developing the contact between the movie and the viewer. This is what produced the results and this is what I wanted to continue to research. Following this line of logic I decided to question if the methods developed could be adapted for teaching in the classroom. Therefore, at the Faculty of Letters University of Lisbon, I proposed a teaching programme for an undergraduate Curricular Unit, C2: English in the World of the Arts, using free associative film analysis. I taught this in the first semester of the 2014/15 academic year and will present the methods and the results below.

This programme of this Curricular Unit followed the guiding principles introduced earlier, but adapted for the classroom and taught in English. Because students were working in English, which is not their native language, I taught free writing to prompts as a creative writing technique. We practised this in class so that students would get used to the idea of writing fluently from a prompt in English without stopping to correct their mistakes. I also analysed two samples of free associative film analysis, Norman Holland's analysis of Casablanca and my own of Elizabethtown with students, so that they could see what free associative analysis looked like and understand the patterns it follows.

In my doctoral research, I had learned that generally participants needed about two weeks to be able to write their free associative analysis texts. I had also learned the importance of watching the movie with the participants and discussing specific connection points. Thus in class, we watched the movies to be analysed together at three-week intervals, discussed possible connection points and students' ideas on the 
aforementioned free associative texts to Casablanca and Elizabethtown. Students had to become proficient in performing both free writing and free associative film analysis and to concentrate on developing the methods, students submitted their free associative analysis two weeks after watching the movies, these exercises were submitted for appraisal and compiled into a portfolio. Then we watched the next movie and repeated the process. In all, students did three short (two-page) free associative analysis texts to the set films, and these texts were a central part of their portfolio.

We did not discuss students' free associative analysis in class, as Holland and Schwartz's students had done, but we considered ideas like Robert Sapolsky's proposals on stress management (2003), current neuropsychoanalytical thinking on the development of consciousness (Solms 2013) and theories on the role reflective thought plays in human development (Corballis 2011), because I wanted students to have an understanding that reading books and watching movies can influence people at a biological, as well as emotional level. As students were not familiar with many of the concepts and ideas discussed, parts of set texts were read in class, contents discussed in smaller groups followed by a full class discussion with rotating spokespeople. Students responded well to the methods and even though many had not read this type of scientific article before, they appeared generally to enjoy doing them.

Besides the portfolio, there were two other evaluation elements, a written test based on the articles read, and a longer written assignment which could be one of the following: a free associative film analysis of a film selected by students, a short story written from a free writing prompt, or an essay on the theoretical aspects of the programme. Students' production both in class and at home was good, but to get some concrete feedback about students' feelings about the programme, and to see if improvements could be made in future editions, I circulated the feedback questionnaire reproduced below at the end of the semester, I asked those students who were interested to complete it and return it anonymously to my college post-box. Sixteen of the forty-seven students enrolled in the class did this

\section{The Feedback Questionnaire}

1. Did you enjoy the classes? If so why?

2. What were the principle notions you took away from the classes? 
3. What were your favourite activities?

4. Were there activities you did not like in the classes?

5. Were there things that could be improved in the class structure?

6. Was performing free associative film criticism productive for you. If yes, why, if not why?

\section{An Overview of Students' Responses to Individual Questions:}

The students who returned the questionnaires wrote extensively, which gave a real idea of what these students felt about the classes. There were often multi-responses I numbered the questionnaires 1-16 arbitrarily and will present very brief summaries of the most common answers to each question. I grouped responses together and because most single responses were similar to group responses I will only refer to isolated answers which this is significant for the overall opinion. Students often listed more than one answer to questions, so that is why some questions have more than sixteen answers.

\section{Question 1 - "Did you enjoy the classes? If so why?"}

All the students answered to the affirmative. 7 students listed the discussion arising from the topics presented and the openness that was permitted in the appreciation of the arts. 3 students enjoyed the discussion of psychological issues. 3 students liked the variety and interest of the topics discussed and movies screened. 4 students enjoyed the way the teacher presented the topics.

\section{Question 2 - "What were the principle notions that you took away from the classes?"}

This was the question that generated the greatest variety of answers, even if some notions were shared by two or three students. I will refer to individual answers here because all the answers lead to an overriding persuasion - students gained new perspectives on the significance of the arts, their understanding of the arts, and/or a different way of thinking about issues. I consider all these points are very relevant and encouraging. 
Three students wrote that the principle notion(s) they took from the programme was that the arts can help people find out more about life, about what they can become and why they feel as they do. 3 others mentioned that free associative film analysis can help us understand ourselves. 3 wrote they think about life and watching movies from different perspectives after doing the course. 2 others thought more about notions of identity, sense of self, recursive thought and stress management. 2 gleaned the notion that the arts are essential for people and society. Single choices included: that we should make more of an effort to see beyond the obvious, thinking about biological processes, that the body and mind are not separate entities, and the notion that feelings can be investigated.

Despite their diversity, all the responses indicate an expansion of thinking patterns, an appreciation of new ideas and new forms of contemplation within the contexts both of formal education and ordinary everyday day lives. These ideas are very relevant when contemplated within the context of the writings of the philosophers Miranda Fricker and ByungChiu Han who respectively consider the development and articulation of individual voices and reflective thought vital for today's society. This point will be further discussed in the next section.

\section{Question 3 - “What were your favourite activities?”}

9 students listed free writing as their favourite activity, and this surprised me. Not surprisingly 8 students listed watching movies and discussing their reactions to them as their favourite activity. 7 mentioned class debates discussing issues referring to many different fields. 6 selected writing free associative film analysis. 3 mentioned that they had really enjoyed the small group discussions.

As the number of answers listed indicate many participants selected more than one favourite activity. I was pleasantly surprised that nine mentioned free writing as a favourite activity, because it is a very good tool for developing creative writing. The threads of thought it produces often lead into unusual and interesting topics. As we were doing this activity in class many students commented that it was difficult at the beginning, but because of free writing they started to write about things they had never consciously thought about, so they found it very enriching. It was also nice to see a balanced blend of preferences for the writing and discussion activities. 


\section{Question 4 - "Were there activities you did not like in the classes?}

Not all the students answered this question but of the ones who did, 6 replied there was nothing they disliked. 8 wrote that they had not really disliked anything much, but if they had to select something it would be - reading the longer texts in class even if this was necessary because of the complex nature of the articles (4 students), breaking into smaller discussion groups (3 students).

\section{Question 5 - "Were there things that could be improved in the class tructure?"}

Again not all the students answered this question, but of the ones who did 5 would change nothing, while 3 students suggested adding more texts on other forms of art appreciation besides free associative analysis to centre the programme more in the arts, and less in biology. Two students suggested applying free associative film analysis to other forms of art. These are valid suggestions and in the next academic year, rather than working with three set films, we will start our analyse work with a movie, but then also work with literature and art.

\section{Question 6 - "Was performing free associative film criticism productive for you. If yes, why, if not why?"}

All students answered this question affirmatively, but one respondent answered both yes and no, so I will return to his/her answer individually in the discussion on this point. 6 wrote they found the exploration of the connections between themselves and the movies highly productive. Five students wrote they learned more about themselves. Other five referred to the fact that this form of writing had improved their writing and/or creative writing skills. Four indicated that they were now more "alert" and less passive when watching movies. Three students liked learning about a new form of film analysis that also expanded their way of thinking. These answers demonstrated a development of critical thought, an increased sense of self awareness, and enhanced writing skills, interesting outcomes from using a method of film analysis. 
There was a very interesting answer on Questionnaire 8 which demonstrated writing free associative film criticism helped this student develop critical skills related to her writing and also solve a personal problem. Student 8 wrote, "Yes, it was very productive for me. It helped me see patterns in my writing and to explain them. One of the exercises we did in class helped me a lot. I was having a recurring dream that was giving me some anxiety and after I wrote about it, I understood it and never had it again" (Martins 2015b: 8). Student 7 answered yes and no to this question, "Yes, because one learns to look inside. No, because it hurts a little" (ibid: 7). So, in this case the analysis seems to have entered some troubled waters, however it did not appear to be very punishing. Similar things had happened with Anna and Anita in their work.

Overall, I consider that students' participation in class and the feedback questionnaires indicate that the classes worked well, both from an academic and personal development perspective. The writing activities did really appear to help students develop their creativity and writing skills, and the quality of the final assignments, whether it was a short story, personal free associative film criticism or an essay was very good. I will be very happy to teach this programme with some minor adjustments again next year.

\section{What contemporary philosophical thought may add}

From the work presented a number of advantages are seen when reflective contact with the arts is encouraged. One of the first advantages seems to be gaining new perspectives which leads to an expansion of the total living experience. Second, participants in the different programmes seem to grow in confidence, as self-awareness is linked with self-acceptance and new ways of dealing with old problems may appear. Thirdly, when there was a need for this, to paraphrase Trounstine and Waxler, reflective contact with the arts seems to facilitate "finding one's own individual and socially conscious voice". But why is this? Some of the thinking in contemporary philosophy can offer some suggestions.

This first issue I will look at is the "finding of one's own voice". Why do people need to find their own voices? After all, speech is developed in the first years of life and most children can communicate competently either verbally or non-verbally from a very early age. So if we already have highly functioning vocal and non-verbal communicative competences, why do we 
need to find a voice through reflective contact with the arts? I believe philosopher Miranda Fricker offers a possible reason in her book Epistemic Injustice: Power and Ethics of Knowing (2007). Fricker proposes that "there is a distinctively epistemic kind of injustice" arising from two different sources: testimonial injustice ${ }^{7}$ and hermeneutical injustice (2009: 1).

The latter refers to situations where society, through its legal and social structures, denies the existence of a certain type of story, so those who are victims to it cannot articulate, or often truly understand what is happening to them if/when they fall victim to the "non-existent" event. For example, Mary Rowe's report for MIT on gender issues, "Saturn Rings" (1974) was one of the first official documents to discuss the concept of sexual harassment. In hindsight, it is common knowledge that sexual harassment existed far before the 1970s; Frier and McGinn discuss sexual harassment as a reality in Ancient Rome (2004: 468-8). However, because sexual harassment was not legally or socially recognized in Western society before the 1970s, it "did not happen", just as marital rape "cannot happen" in some societies today. Because there was/is no socially acceptable vocabulary to describe these events, victims are rendered to silence for the lack of words, and must develop strategies to deal with the havoc this silence will provoke in their lives and minds. The notion of hermeneutical injustice is central to understanding how an individual may be denied a voice from an institutional stance as it looks at the inability of society to see or discuss a subject.

Fricker's conception of testimonial injustice is relevant to the discussion of the advantages offered by reflective contact with the arts, because she considers testimonial injustice refers to the silencing of individuals because it denied them the capacity to be considered credible knowers and tellers of their own stories. Many mechanisms including stereotyping and the construction of identity power combine to cast people as unreliable transmitters of knowledge about themselves, their lives and living conditions and to negate their competence to be considered knowers of their own stories. According to Fricker incredulity and misinterpretation leading to silencing are socially accepted patterns often used when refusing to hear the stories of others. A kind of identity power is exerted, which divides society into those who can be seen as authentic knowers and withholding credibility from speakers because they are members of a certain social type. This leads to identity prejudices.

\footnotetext{
7 The italicization of terms in this section follow Fricker's usage.
} 
Fricker illustrates her point about identity power and identity prejudices using Anthony Minghella's screenplay of The Talented Mr. Ripley (2000). The film is set in the 1950s when women were not really considered to be knowers of matters outside the female domain, and the dominant identity is a powerful male one. Towards the end of the movie, following a bizarre series of events that Tom Ripley is always involved in, Marge Sherwood becomes suspicious that Ripley is responsible for her fiancé Dickie Greenwood's disappearance. Her suspicions are confirmed when she finds Dickie's two distinctive rings in Ripley's possession. She also understands that she barely missed harm herself through the chance appearance of a friend in Ripley's flat. However, when Marge presents this evidence to Dickie's father, the wealthy and powerful Herbert Greenleaf, he dismisses it saying "Marge, there's female intuition, and then there are facts" (2000: 130). The dominant identity - successful, white male businessman - silences a voice of reason through incredulity and misinterpretation because the story is told by someone not considered at the time to be a faithful knower. The young woman, who tells the counter story is a character the dominant identity sees as too fragile and griefstruck to be capable of being a competent witness of events, despite the fact that her character is portrayed as intelligent, sensitive and socially aware throughout the film.

According to Fricker, power structures, including those arising from epistemic injustice lead to "a socially situated capacity to control others' actions" (2009: 4). Depending on the psychology of the individual (and I would also add the degree of exclusion their social circumstances, entails), when social domination is deep "it can cramp self-development, so that a person may be, quite literally be prevented from becoming who they are" (ibid: 5). Based on the programmes presented in this essay, it might be suggested that platforms which encourage reflective contact with the arts offer individuals the capacity to encounter their own voices in a non-judgmental fashion. Free associative film analysis may be seen as a particularly interesting tool. Because of its explorative nature it may assist individuals to grow into and embrace personal identity, endowing the confidence to acclaim unusual yet individually appropriate lifestyle choices that may conflict with dominant collective narratives, as Aida did. 
Philosopher, Byung-Chul Han's, proposals in The Burnout Society $(2010)^{8}$ illustrate other benefits that reflective contact with the arts might offer in today's society. He introduces his essay suggesting that the neurological illnesses plighting the lives of so many in the twenty-first century are the product of a society dominated by excessive positivity, a society that expects its members to be always ready to say yes, to produce and act, but not to stop and think. While the diseases of the past were caused by foreign agents, mainly bacterial and viral, and combated by fighting external others, Han considers today's diseases are generated internally, and so cannot be treated in a similar fashion. He writes:

Neurological illness such as depression, attention deficit hyperactivity disorder (ADHD), borderline personality disorder (BDO) and burnout syndrome mark the landscape of pathology at the beginning of the twenty-first century. They are not infections, but infractions; they do not follow from the negativity of what is immunologically foreign, but from an excess of positivity. Therefore, they elude all technologies and techniques that seek to combat what is alien (2015: 1 ).

In an interview given to Literaturen magazine and reprinted in English on the signandsight.com web site, Han explained that he sees this positivity in "the perseverance slogan of positive thinking" prompted by the dictates of increased efficiency, leading both "master and slave" to constantly compete with themselves to perform better in order to achieve reward and the elusive promise of leisure. Unfortunately this is an unrealised goal and all end up working like slaves. Han suggests "The performance society [...] creates depressives and failures. In short, the problem today is not the other, but the self (which constantly and emphatically says "Yes"!)" (2011).

In The Burnout Society, Han suggests two elements feed into this mind set enhancing the establishment of neural patterns that support its structure: multi-tasking and video gaming. While these are considered by many as marvels of our age and demonstrative of human creativity and evolution; Han holds them to be highly prejudicial because they lead people to be constantly neurologically wired. Han writes, "Not just multitasking, but also activities such as video games produce a broad but flat mode

8 Originallypublishedin Germanin Berlin by Matthes \& Seitzin 2010 as Müdigkeitsgesellschaft, and translated into Spanish as La sociedad del cansancio. Barcelona, Herder Editorial, 2012, it has only been translated into English in 2015 by Stanford University Press. 
of attention, which is similar to the vigilance of a wild animal" (2015: 13), thus Han argues humans are returned to primal animal states. Han suggests we can see amply signs of this return to a "savage" life, as bullying achieves pandemic proportions and individual survival becomes a greater concern than the wellbeing of society as a whole (2015: 13-14).

Curiously, Han does not see multitasking as an exclusively human activity. He refers to the fact that animals in the wild have to multitask to protect themselves from predators while procuring the food, shelter and mating conditions they need to survive and reproduce. Han suggests, "We owe the cultural achievements of humanity - which include philosophy - to deep contemplative attention. Culture presumes an environment in which deep attention is possible" (2015]: 13). Thus, if one takes Han's suggestions seriously the reflective thought (made possible by the literature programmes presented in this essay) is positive for the development of thinking individuals, even if these do not belong to disenfranchised groups. The development of reflective thinking requires a slowing down of the hyper-attention mode activated through multitasking, "Learning to see means "getting your eyes used to calm, to patience, to letting things come to you"' (2015: (21). Watching an engaging movie, where no cell phones or IT gadgets can be used, is probably one of the easiest and least "painful" ways of doing that today. The selection of the connection points and subsequent free associative writing to them might encourage the development of the "deep and contemplative attention" which is necessary for the reflective thought. Thus perhaps reflective contact with the arts could also explain the increased confidence seen in many of those who participated in the programmes mentioned, and the reduction in anxiety levels recorded in the individual free associative film analysis trials.

\section{Final thoughts}

While this essay involves tools and knowledge from many different fields, its heart lies in the arts. Looking at innovative programmes in musical and literary education it demonstrates how contact with the arts can influence people's lives positively. It offers insight as to how significant contact with the arts, in particular film and literature, may help people expand their total living experience. In this closing section of the essay, two questions must be addressed to make the proposals presented cohesive. The first 
one is, what are "the arts" in the context of this essay? The second what is significant contact with the arts?

I will answer the first question referring to Norman Holland's views on the purpose of the arts presented in Literature and the Brain (2009). Holland discusses the universality of literature and the arts in all human societies. He explores the notion that the brain is used differently when processing fictional narratives, and he looks at how interacting with fictional narratives can permit people to encounter and understand circumstances outside their actual lived experience, Referring to neuropsychoanalysis Jaak Panksepp's proposals on the necessity of play for the organisation of the mature mind, he discusses how psychoanalysts from Freud onwards have considered the arts as a means of perpetrating this maturation into an age where play is no longer a feasible option (Holland 2009: 321-332). I consider the key how "the arts" can be interpreted with the context of this essay can be found in Holland's description of what literature can do for people. Holland writes "Literature therefore helps us to live better, in Winnicott's view, because it allows us to loosen the boundaries: between self and non-self; inner and outer; past, present and future; or using and enjoying (Kant's "disinterestedness"). The arts help us to get back to a time when we were not so rigidly compartmented into our working and playing and loving selves" (ibid: 330). Thus I consider the arts in the context of this essay includes any form, where the authors have striven to ask the questions of our common humanity and so produce external objects that allow for the deep reflection of these same questions.

To answer the second question, what is significant contact with the arts, we must look at the programmes and examine the type of contact they implied. In all the programmes, an open interaction with the art form being studied was central and those working on the programmes believed in the transformative power of the arts. This was the case whether they worked on prevention as "El Sistema", rehabilitation as CLTL, or teaching reflective film and literary analysis. According to José Abreu the central treatise of "El Sistema" is that "music has to be recognized as an agent of social development, in the highest sense because it transmits the highest values - solidarity, harmony, mutual compassion. And it has the ability to unite an entire community, and to express sublime feelings" (Tunstall 2012: 273). Establishing the ground rules for the application of CLTL, Professor Robert Waxler held that anyone working with CLTL had to consider that "literature has the power to transform" (Trounstine \& Waxler 2005: 5) and 
"literature was still the most important tool we had to humanize ourselves and our society" (ibid: 62).

Another argument is worth calling to mind. While the above programmes strive to create a genuine connection between the individual and the external artistic object and share a belief that through understanding/ use/discussion of this unique link living experiences can be expanded and every individual can be integrated as valid members of society; they also require discipline in application even if they permit open interpretation. Free associative film analysis could be seen as a tool to achieve this type of interaction in a regular teaching environment because it encourages open interaction, but also requires discipline in application. Perhaps other methods can also be sought and the fields of film and literary studies would benefit from this, if this type of work encouraged the developing of reflective thought, a feature so sadly missing in contemporary society according philosopher Byang-Chul Han's opinion. Conceivably there has never been a better time to study the arts!

\section{References}

Ardolino, E. (dir) (1987) Dirty Dancing, Great American Films Limited Partnership, DVD.

Crowe, C. (dir) (2005) Elizabethtown, Paramount Pictures.

Domenech, C. (2014) "Poetry that frees the Soul, TedxRiodelaPlata, trans. Sebastian Betti, [online] Available at https://www.ted.com/ talks/cristina_domenech_poetry_that_frees_the_soul?language $=\mathrm{en}$. Accessed $3^{\text {rd }}$ Feb 2015.

Fricker, M. (2009) [2007] Epistemic Injustice: Power and the Ethics of Knowing. Oxford \& New York: Oxford University Press.

Frier, B \& McGinn, T (2004) A Casebook of Roman Family Law. Oxford: Oxford University Press.

Han, Byang-Chul (2015) [2010] The Burnout Society, trans. Erik Butler, California: Stanford University Press.

(2011) From pasta to pyrotechnics - Play more and work less: A visit with Byung-Chul Han in Karlsruhe". In Let's Talk European signandsight. com [online] Available at http://print.signandsight.com/service/2156. html. Accessed $5^{\text {th }}$ May 2015. 
Holland, N. (1975) 5 Readers Reading. New Haven \& London: Yale University Press.

(1998) The Mind and the Book: A Long Look at Psychoanalytic Literary Criticism. [online] Available at http://www.clas.ufl.edu/users/ nholland/mindbook.htm. Accessed 7th Februrary 2010.

(2006) Meeting Movies. Madison \& Teaneck: Fairleigh Dickinson University Press.

Holland, N. and Schwartz, M. (2008) Know Thyself Delphi Seminar. Gainesville Fl: The PsyArt Foundation.

(2009) Literature and the Brain. Gainesville Florida: The PsyArt Foundation.

Leder, M. (dir) (2000) Pay It Forward. Warner Brothers Pictures, DVD.

Lichtenstein, H. (1961) Identity and Sexuality-A Study of their Interrelationship in Man. In Journal of the American Psychoanalytic Association, 9 179-260 PEP Archive [Online database] access number APA.009.0179A. Accessed $2^{\text {nd }}$ June 2008.

Martins, C. B. (2012) Simple Stories. Dissertation, University of Lisbon. [online] Available athttps://docs.di.fc.ul.pt/bitstream/10451/8015/1/ ulsd064291_td_Cecilia_Martins.pdf. Accessed 29 ${ }^{\text {th }}$ March 2015.

(2015a) Gaining Awareness \& Acceptance of Self and Developing Coping Skills through Film Analysis. In Narrativa e Bioética. Lisbon: Centro de Bioética, Faculdade de Medicina Universidade de Lisboa pp 117-132.

(2015b) English in the World of the Arts:C2 - Class Questionnaires, Author's Compilation.

Minghella, A. (2000) The Talented Mr. Ripley — screenplay based on Patricia Highsmith's novel. London: Methuen.

Rowe, M. (1974) "Saturn's Rings" Graduate and Professional Education of Women, American Association of University Women pp1-9.

Solmes, M. (2013) The Conscious Id. In Neuropsychoanalysis, 15, pp5-19. Spielberger, C., et al (1983) State-Trait Anxiety Inventory for Adults Sampler Set: Manual, Test Booklet and Scoring Key. Palo Alto: Consulting Psychologists Press.

Tunstall, T. (2012) Changing Lives. W\&W. Norton.

Trounstine, J \& Waxler, R (2008) [2005] Finding a Voice: The Practice of Changing Lives Through Literature. USA: University of Michigan.

Received: 20 August, 2015

Accepted for publication: 10 September, 2015 
Сесилија Бичер Мартинс

АНАЛИЗА СЛОБОДНИХ ФИЛМСКИХ АСОЦИЈАЦИЈА

\section{Сажетак}

Може ли интимни доживљај уметничког дела проширити хоризонт људског искуства? Резултати који су добијени на основу примене програма који анализирају разне врсте социјалног понашања у контексту визуелних уметности, музике (Tunstall 2012) и књижевности (Trounstine \& Waxler 2008) говоре управо у прилог томе. У студији Meeting Movies (2006) Норман Холанд (Norman Holland), представља рефлексивни метод анализе у контексту филма - анализе на основу слободних филмских асоцијација. У свом есеју предствићу сопствени начин адаптације метода индивидуалних слободних филмских асоцијација у настави као и резултате добијене његовом применом. Представићу резултате који су добијени у поменутом истраживању у светлу тврдњи које је поставила филозофкиња Миранда Фрикер (Miranda Fricker) о епистемолошкој неправди (2006) и Бјанг-Чул Хан (Byung-Chul Han) о друштвеним и неуролошким коренима обољења као што су депресија, дефицит пажње и поремећај хиперактивности (ADHD), гранични поремећај личности (BDO) и бернаут синдром (2010), са циљем да укажем на значај уметности и потребу за њеним проучавањем која је, чини се већа него икад раније!

Кључне речи: филм, уметности, образовање, анализа на основу алободних филмски асоцијација, друштвени учинак 